\title{
IMPLEMENTATION OF THE DÉFENSE PUBLIC POLICY DEFEND THE STATE IN INDONESIAN UNIVERSITIES
}

\author{
Lukman Yudho Prakoso, Universitas Pertahanan \\ Gazali Salim, Universitas Borneo Tarakan \\ Julian Ransangan, Malaysia Sabah University \\ Subhilhar, Universitas Sumatera Utara \\ Agus Indarjo, Universitas Diponegoro \\ Yusriadi Yusriadi, Sekolah Tinggi Ilmu Administrasi Puangrimaggalatung
}

\begin{abstract}
Indonesia in May 2018 was again shocked by the act of terrorism in the form of an explosion that occurred in urban areas on three Surabaya churches carried out by one family, the next action was an explosion in the North Surabaya Police Resort City with a suicide bombing involving one family as well. This fact is an indicator that the nation must re-evaluate the country's defence, which is carried out by the people. The perpetrators have been living with the community all this time but have escaped our mutual attention. Terrorism and radicalism cases also continue to thrive among universities, both state and private, especially those in urban areas. Therefore, it is necessary to re-examine how the implementation of state defence which has been carried out in higher education. In this study the method used is descriptive phenomenological quality and the theory used is the theory of public policy implementation George Edward III. The results of the study show that communication between stake holders is still running independently and has not been integrated and coordinated optimally, the resources used are still carried out individually which results in ineffective and inefficient, disposition (authority) regarding state defence still has its own perceptions between agencies, the bureaucratic structure also has not shown the achievement of effective and efficient goals.
\end{abstract}

Keywords: Defence State, Public Policy Implementation, Universities, Urban Areas

\section{INTRODUCTION}

Based on the 2015 National Defence White Paper, terrorists are still a threat to the Indonesian people in the future. This is evidenced by the development of terrorist networks after the destruction of Al-Qaeda by the United States. Seeing from this condition, the government needs to immediately determine its position and take anticipatory actions to prevent acts of terror. In addition to making persuasive efforts, the law enforcement side must also be given a balanced portion. Citing the Routine Activities theory proposed by Marcus Felson and Lawrence E. Cohen in 1979, crime will arise if there are three components in the same space and time, namely: motivated offenders, suitable targets (appropriate targets) and the absence of capable guardians or protectors (no guards or protectors).

The perpetrators of acts of terrorism and radicalism in Indonesia mostly come from students and students (BNPT, 2012). Based on research on 110 perpetrators of terrorism in 2012, most were in the age range of 21-30 years (47.3 percent), after that in the age range of 31-40 years (29.1 percent) and 11.8 percent under age 21 years old (BPNT, 2016).

Seeing the cases that have existed lately, the fact that more young terrorists are hard to disprove. The same year survey of potential radicalism in the student environment showed 26.7 percent agreed to jihad with the use of violence, while those who did not agree 68.4 percent. 
Besides that, the facts also prove the results of a survey from the BNPT in 2016 saying that terrorists came from educated circles BPNT, 2016.

The ease of students and students to become sympathizers of radical groups affiliated with ISIS is because they are still in the search phase of identity, emotionally immature, so that they are easily influenced by new ideas. In addition, their adventurous spirit is still large, so they tend to try something new and full of challenges.

The phenomenon of the number of students becoming sympathizers of radical groups is strengthened by the results of a recent survey from the research institute Alvara Research Centre in 2017 stating that radicalism has been among students and students. The Alvara Research Centre conducted a survey of the attitudes and views of students and students about religious radicalization, khilafah, jihad and Islamic states in Indonesia. The result is that students agree with the Islamic state by $23.5 \%$ and for students agree with the amount of $16.3 \%$. Furthermore, the state ideology, the result is that most students and students choose the Pancasila ideology. The percentage of students choosing Islamic ideology is $18.6 \%$ and students are $16.8 \%$ (Faqif, 2017)

From the description above, the threat of terrorism in 2017 in Indonesia is still very strong. Therefore, integrated steps are needed from the government and the community so that there are no vulnerabilities utilized by radical groups to carry out their actions. One effort to counter radicalism is a state defence program, which among others is carried out by the Ministry of Defence. Defence Minister Ryamizard Ryacudu said, the Bela Negara program was launched and became the Ministry of Defences' priority program, one of the goals and objectives was to establish the identity and personality of the Indonesian nation (Lukman et al., 2021; Hussain, Quddus, Pham, Rafiq \& Pavelková, 2020).

The State Defense Program is a form of mental revolution as well as to develop the nation's deterrence in facing the complexity of the threat dynamics as well as to realize national resilience. Martial arts are actualized in the roles and professions of every citizen. The state defense program is one of the government's policy efforts in empowering national defense which is regulated in Presidential Regulation number 97 of 2015 concerning General Policy on National Defense (Suhirwan \& Prakoso, 2019).

\section{PROBLEM FORMULATION}

The acts of terrorism and radicalism that occurred in Indonesia especially those involving students were of particular concern in this study, because students are the generation that determines the future of the nation in time, so that in this study the formulation of the problem presented is how to implement government policies on defense Which countries are currently implemented in universities especially those in urban areas?

\section{THEORY AND METHOD USED}

In this study the theory used is the theory of implementation of public policy according to George Edward III there are four variables in public policy namely Communication, Resources, attitudes, and bureaucratic structures (Edward, 1980) The type of research used is descriptive qualitative phenomenology.

\section{DISCUSSION}

According to the results of the 2017 National Intelligence Agency (BIN) survey, 39 (thirty-nine) percent of students have been exposed to radical movements, there are 15 (fifteen) provinces that have now become BIN's attention and continue to receive attention. Of the 15 (fifteen) provinces there are three universities which are the main concern because they are the basis for the spread of radicalism. The phenomenon of radical teaching among students utilizes 
psychological innocence in students who are still in the process of finding identity (Rivai, 2018; Hussain, Quddus, Pham, Rafiq \& Pavelková, 2020). BIN gave an example that Bahrun Naim was a young man who began to engage with radical activities while studying at Sebelas Maret University in Surakarta (Madrohim \& Prakoso, 2021)

Judging from the legislation, the obligation to defend the country can be traced to the provisions of the 1945 Constitution and law number 3 of 2002 concerning national defense. In the 1945 Constitution Article 30 paragraph 1, it is affirmed that "each citizen has the right and obligation to participate in the defense and security efforts of the state". Whereas in paragraph 2 it is stated that "the defense and security efforts of the state are carried out through a system of defense and public security by the TNI and POLRI as the main force, and the people as supporting forces."

The concept stipulated in Article 30 is the concept of defense and state security. While the concept of defending the state is regulated in Article 27 paragraph 3 of the 1945 Constitution that "Every citizen has the right and obligation to participate in efforts to defend the state". Participating in the defense of the country is manifested in the implementation of national defense activities, as stated in Law No.3 of 2002 Article 9 paragraph (1) that "Every citizen has the right and obligation to participate in efforts to defend the state which is manifested in the implementation of national defense". Then in Republic of Indonesia Law number 3 of 2002 the section weighing letters (c) is affirmed among other things "in the implementation of national defense every citizen has the right and obligation to participate in efforts to defend the state ...".

Our problem now is how to manifest the participation of citizens in efforts to defend the country. According to Article 9 paragraph (2) Law number 3 of 2002 concerning National Defense, the participation of citizens in efforts to defend the country is carried out through:

a. Civic education.

b. Mandatory military basic training.

c. Devotion as an Indonesian National Army soldier voluntarily or compulsorily; and

d. Dedication in accordance with the profession.

Based on these provisions, students who take Citizenship Education subjects in schools can be said to have participated in the state's defense efforts. One of the study materials that must be contained in the basic and secondary education curriculum and higher education is Citizenship Education (Article 37 paragraph (1) and (2) Law Number 20 of 2003 concerning the National Education System). The problem that we want to explore is why can state defense efforts be carried out through civic education?

In the explanation of Article 37 paragraph (1) of the law, it is explained that citizenship education is intended to form students to become human beings who have a sense of nationality and love for the country. From the description above, the formation of a sense of nationality and love for the homeland of students can be fostered through citizenship education.

The concept of nationalism and love of homeland is closely related to the meaning of the country's defense efforts. Note the phrase ". in the spirit of his love to the united states of Indonesian Republic." in the definition of state defense efforts that have been disclosed above. The sentence of love for the unitary state of Indonesia is the realization of the concept of nationalism (a sense of nationality) and the love of the country (patriotism). Whereas love for the homeland and national awareness is a feature of awareness in defending the country. (Darmawan, 2004) asserts that the concept of state defense is a moral conception that is implemented in the attitudes, behavior and actions of citizens based on: love of the homeland, awareness of nation and state, belief in Pancasila as a state ideology, and willingness to sacrifice for the nation and state of Indonesia. Thus, in relation to defending the country, citizenship education is a vehicle to foster awareness of students participating in the defense of the state (Risahdi et al., 2020; Hussain \& Hassan, 2020).

In addition, we can see by tracing the juridical provisions of Article 9 paragraph 2 (letter a) of Law Number 3 of 2002 which states that "in citizenship education there is an understanding 
of the awareness of defending the country." This means that one way to gain an understanding of awareness of defending the state can be achieved by taking citizenship education.

Darmawan (2004) emphasizes that citizenship education, in addition to teaching citizens' rights and obligations, has included an understanding of the state's defense awareness for national defense. Then he stressed that the obligation to include citizenship education in the basic, secondary, and high education curriculum is a manifestation of the participation of citizens in efforts to defend the country in the context of the implementation of National Defense.

Thus, fostering awareness of defending the country through citizenship education is intended to foster and improve national defense efforts. (Malik fajar, 2004) asserts that Citizenship Education has the duty to instill national commitment, including developing democratic values and behavior and being responsible as Indonesian citizens.

Radicalism and terrorism in universities such as the results of research conducted by BIN is a big question, how has the implementation of state defense implemented in universities, the following are the results of research related to the implementation of defense in higher education from variable analysis of George Edward's public policy implementation theory III, the location of research in retrieving secondary data and primary data is carried out based on past bases of radicalism and terrorism movements, the locus covers Lampung Province in Bandar Lampung City and its surroundings, in West Java Province in the cities of Purwakarta and Bandung, in East Java in the City of Surabaya, in South Sulawesi in the City of Makassar and in the Jakarta Special Capital Region (DKI) as a Center of Gravity (COG) for terrorism:

\section{Communication}

Based on George Edward III, communication greatly determines the success of achieving the objectives of the implementation. Effective implementation occurs when decision makers already know what will be done. Communication is further divided into 3 determinants of successful policy implementation, including:

\section{Transmission}

Transmission is the main factor in terms of communication of implementing policies. According to Agustino, the distribution of good communication will result in a good implementation (Leo, 2008). There is often a problem in channeling communication that is misunderstanding, so that what is expected is distorted in the middle of the road.

Transmission on the implementation of the State Defense is carried out by the Ministry of Defense in this case represented by the Directorate General of Defense Potential to the regional government as the implementing policy then forwarded to the local government work unit through direct or verbal orders (Redita et al., 2020).

The results of the team's findings in the field found that almost all research locus occurred miscommunication and miscoordination of the implementation of State Defense in the regions. The causes of miscommunication and miscoordination are because the delivery of messages to the regions is done in a hurry then from the center to the regions not through appropriate procedures in the area.

\section{Clarity}

According to George Edward III, communication received by policy makers (streetlevel-bureaucrats) must be clear and not confusing or unambiguous. The implementation of the National Defense program in the regions from the results of interviews with several informants said that local governments need clarity related to this program, they need a legal umbrella for implementing the State Defense so that local governments can work optimally. The legal basis referred to here is the existence of derivative regulations from the Defense Law specifically regulating State Defense (Kurniawan et al., 2018). 


\section{Consistency}

According to George Edward III, the orders given in the implementation of a communication must be consistent and clear to be determined or executed. If the order given often changes, it can cause confusion for the implementer in the field. Therefore, consistency must also get attention in a communication. Consistency in the implementation of the State Defense in the regions has been going very well so far, the regional government is very consistent in supporting the State Defense program (Prihantoro et al., 2021).

\section{Resource}

Resources are important factors for the implementation of policies well, so that sufficient human resources (HR) are needed and enhanced capabilities possessed by policy implementers. The resources here are divided into two, namely in the form of human (staff) and non-human resources (infrastructure facilities or advice).

\section{Staff}

Implementation of policy will not succeed without the support of qualified human resources, quality in this case is from education, experience, competence, and professionalism and besides quality is the quantity of the staff themselves who will implement the policy.

Human resources are very influential on the success of implementation, because without reliable human resources policy implementation will not run smoothly. The human resources (staff) referred to in terms of implementing the State Defense policy in the regions to prevent terrorism, especially being a foreign terrorist fighter, are the availability of official Martial Arts instructors or instructors from the Ministry of Defense (Suhirwan et al., 2020).

The findings in the field at the time of the interviews in several regions found that there was a shortage of teaching staff to provide materials for State Defense, teachers who had been using teachers from outside the Ministry of Defense so far, such as Kodam, Korem and Kodim. One example that was considered successful in overcoming the shortcomings of competent teaching staff was in Purwakarta Regency, where the Purwakarta Regent employed a former terrorist named Agus Marshal to teach at the ideology school formed by the Purwakarta Regent.

\section{Facilities}

Facilities are a very necessary factor in implementing a policy. Facilities here can mean in the form of buildings, educational materials, and curriculum and so on. The facilities in implementing the National Defense policy in the regions as a result of the findings and interviews are the unavailability of special Martial Arts training centers for regions, so far, the participants deposited in Rindam in the area meanwhile the Ministry of Defense is currently only available in Bogor Rumpin Training Center which was just inaugurated in February 2017. In addition to the building facilities that are needed there is also a need for a basic Bela Negara curriculum that has standardized from the Ministry of Defense. This curriculum contains the types or subjects that should be given to participants especially in relation to this research for students to prevent becoming foreign terrorist fighters (Dipua et al., 2020).

\section{Disposition}

Disposition or attitude of implementing policies is an important factor in the approach to implementation or public policy. If the implementation of a policy wants to be effective, then the implementers of the policy must not only know what will be done but also must have the ability to implement it, so that in practice there is no bias (Lukman et al., 2020). 
The attitude of implementing the policy will be very influential in implementing the policy. From the findings in the field during interviews with informants such as the Head of the East Java Provincial Kesbangpol, Director of Student Affairs, Airlangga Regional Head of East Java supported the Bela Negara program, they saw the Bela Negara program very good and important to foster a sense of love for the country and fight terrorism (Lukman \& Aprilliyani, 2021).

In addition, the results of interviews with Unair's Student Director and Unila's Vice Chancellor III also supported that the State Defense be included in the education curriculum in higher education and there was a need to modify the delivery of materials for students to the State. From several informants, they said that they supported the State Defense for students not in a militaristic form, but could be in the form of public lectures, field work practices, museum visits, and other positive activities.

\section{Bureaucratic Structure}

Bureaucratic structure has a significant influence on policy implementation. This aspect of bureaucratic structure includes two things, namely mechanism and fragmentation Rifqi \& Prakoso, 2020).

\section{Mechanism}

The mechanism meant in the bureaucratic structure of policy implementation is the existence of a Standard Operational Procedure (SOP) (Sartono, Prakoso \& Sianturi, 2019). In relation to the implementation of the State Defense, what is needed now is a guideline for the implementation of the State Defense program, which is endorsed by the Ministry of Defense, besides that the Ministry of Defense must initiate the submission of a presidential decree regarding the implementation of regional defense (Listiyono et al., 2019a).

This presidential decree is deemed necessary in the regions because the regions need a clear legal umbrella related to this State Defense, in addition to that, it is also necessary to regulate the mechanism for the inclusion of special Martial Arts material into the student curriculum. This is in accordance with the statement from Minister of Technology Research and Higher Education Muhammad Nasir that to prevent radicalism in the campus, the National Defense program for students will be implemented, this program is in the form of general education in which there are national insight material (Yulida, 2018) to introduce back to students about the country of Indonesia.

\section{Fragmentation}

Fragmentation according to George Edward III is the division of responsibility for a policy area among organizational units. Responsibility for a policy area is often spread among various organizations; this responsibility can be in the form of socialization, training and services.

In the implementation of the National Defense in the regions, the results of data collection in Mataram, Lampung, Surabaya, Purwakarta, Bandung and Bogor found that coordination in the implementation of State Defense actually had gone well, as evidenced by the results of hearings with the Head of the East Java Province Kesbangpol which explained Kesbangpol East Java Province with the Representative of the Ministry of Defense (PPTP) in East Java has often coordinated and implemented the Martial Arts program in East Java, but one thing that has not been implemented is the entry of State Defense into universities in East Java, especially in Surabaya (Sartono, Prakoso \& Suseto, 2019).

\section{CLOSING}


The conclusion of this study was faced with the results of the analysis of the implementation of state defense policies in higher education. It was found that the State Defense in higher education applied to the tertiary education curriculum, which was specifically in urban areas, was not enough to counteract radicalism and terrorism that entered universities. It was found that the stake holders related to defending the country did not have good communication, so that the utilization of resources was not optimal, communication that was not well established also had an impact on the attitude of implementing state defense in higher education. Communication problems between stakeholders also have an impact on the system that is still not well integrated, the bureaucratic structure related to the model of the national defense model through the civic education model currently being implemented at the beginning of the semester is also felt to be lacking so that the national defense model in universities must be reevaluated and together with other stake holders must have strong communication so that the phenomenon of higher education especially in urban areas is exposed to radicalism and terrorism can be overcome.

\section{REFERENCES}

Ali, I.M., Prakoso, L.Y., \& Sianturi, D. (2021). Marine defense strategy in facing maritime security threats in the indonesian sea territory. Marine Defense Strategy, 6(2), 169-188.

Arto, R.S., Prakoso, L.Y., \& Sianturi, D. (2019). Indonesian marine defense strategy in maritime perspective facing globalization. Marine Defense Strategy, 5(2), 65-86.

The white paper of the state defense of the republic of indonesia in 2015.

Dipua, A., Hermawan, R., Puspitawati, D., Harahap, N., Rizanny, D., \& Prakoso, L.Y. (2020). An analysis of the south china sea conflict: Indonesia's perspectives, contexts and recommendations. PalArch's Journal of Archeology of Egypt/Egyptology, 17(4), 976-990.

Faqih, H. (2018). Kemenristekditi study survey on radicalism among students, accessed on date.

George III Edward: Implementing public policy, 1980

Harris, A., Prakoso, L.Y., \& Sianturi, D. (2019). Marine defense strategy in the context of security threats in the indonesian archipelago sea lane II. Marine Defense Strategy, 5(1), 15-30.

Hermawan, T., Prakoso, L.Y., \& Sianturi, D. (2020). Marine defense strategy in impact analysis and government efforts to secure indonesian archipelagic sea lanes. Marine Defense Strategy, 6(3), 273-296.

Kurniawan, C., Widyarto, S., \& Prakoso, L.Y. (2018). Implementation of the bureaucratic structure of the marine defense strategy in facing threats in the waters of southeast sulawesi province. Marine Defense Strategy, 4(1), $1-18$.

Kusuma, A.W., Prakoso, L.Y., \& Sianturi, D. (2019). Synergy of fleet command I and the indonesian maritime security agency in the marine defense strategy to eradicate transnational crime in the malacca strait. Marine Defense Strategy, 5(2), 51-64.

Prakoso, L.Y., Kusuma, A.W., \& Sianturi, D. (2021). The relevance of the marine defense strategy based on the jalesveva jayamahe doctrine to globalization and the development of the strategic environment. Marine Defense Strategy, 6(1), 77-100.

Lawrence, E.C., \& Marcus, F. (1979). American sociological review.

Listiyono, Y., Prakoso, L.Y., \& Sianturi, D. (2019). Building Indonesian sea power is seen from the Indonesian sea guard and deterrence effect. Indonesia building Indonesian sea power based on the Indonesian sea guard and deterrent effect. Marine Defense Strategy, 5(1), 73-84.

Listiyono, Y., Prakoso, L.Y., \& Sianturi, D. (2019). Marine defense strategy in securing indonesian archipelago sea lanes to realize maritime security and maintain indonesian sovereignty. Marine Defense Strategy, 5(3), 103116.

Leo, A. (2008). Fundamentals of public policy. Alphabeta, Bandung.

Madrohim, M., \& Prakoso, L.Y. (2021). The total war strategy through the improvement of the role of national shipyard in supporting main weapon system of indonesian navy. Journal of Social and Political Sciences, 4(1).

Presidential Regulation number 97 of 2015 concerning General Policy of State Defense.

Prakoso, L.Y., \& Aprilliyani, R. (2021). Implementation of electrical engineering in defense and military sector, (1st edition). (K. Prihantoro \& S. Suhirwan, CV. Global Aksara Akademia).

Prakoso, L.Y., Suhirwan \& Prihantoro, K. (2020). Sea defense strategy and urgency of forming maritime command center. Journal of Defense, 6(2), 200-211.

Prakoso, L.Y., Prihantoro, K., \& Suhirwan, S. (2021). The urgency of networking transformation and defense policy driver force. C.V. Academic Global Script.

Prasetyo, K.A., Prakoso, L.Y., \& Sianturi, D. (2019). The Indonesian government's maritime defense strategy in maintaining maritime security. Marine Defense Strategy, 5(1), 31-50. 
Prihantoro, K., Prakoso, L.Y., Suhirwan, S., \& Kusmiati, M. (2021). AHP SWOT method in planning defense strategy. CV. Academic Global Script.

Rivai, A. (2018). Campus becomes a place for radical understanding to grow, 39 percent of students have been exposed.

Redita, W., Prakoso, L.Y., \& Hipdizah. (2020). Implementation of the vessel traffic services policy of the directorate general of sea transportation in the sunda strait in shipping safety against the marine defense strategy. Marine Defense Strategy, 6(1), 31-44.

Rifqi, M., \& Prakoso, L.Y. (2020). Policy implementation in handling transnational crimes in indonesia sea. International Conference On Business \& Social Science.

Risahdi, M., Jaddawi, M., Henny, A., Prakoso, L.Y., \& Martani, W.R.M. (2020). Ambiguous policy on securing the vital objects of the indonesian armed forces in east java. Public Policy and Administration Research, 10(1), 52-56.

Hussain, S., \& Hassan, A.A.G. (2020). The reflection of exchange rate exposure and working capital management on manufacturing firms of pakistan. Talent Development \& Excellence, 12(2).

Hussain, S., Quddus, A., Pham, P.T., Rafiq, M., \& Pavelková, D. (2020). The moderating role of firm size and interest rate in capital structure of the firms: Selected sample from sugar sector of Pakistan. Investment Management and Financial Innovations.

Prakoso, \& Aprilliyani. (2021). Implementation of electrical engineering in defense and military sector (K. Prihantoro \& S. Suhirwan (eds.); 1st edition). CV. Academic Global Script.

Sartono, P.L.Y., \& Sianturi, D. (2019). Government policy in efforts to handle illegal fishing in the viewpoint of state defense at sea. Marine Defense Strategy, 5(1), 51-72.

Sartono, P.L.Y., \& Sianturi, D. (2020). Impression and government authority in securing indonesian archipelagic sea lanes (ALKI). Marine Defense Strategy, 6(3), 231-256.

Sartono, P.L., \& Suseto, B. (2019). Indonesia's sea power balance today faced with geopolitics of the asia pacific region. Marine Defense Strategy, 5(2), 87-114.

Suhirwan, \& Prakoso. (2019). Defense strategy at sea handling of Transnational Organized Crime (TNOC) in nunukan Indonesia's national sea border. IOP Conference Series: Earth and Environmental Science, 339, 12043.

Suhirwan, \& Prakoso. (2019). Maritime forum is the key to success in mitigating asymmetric threats in the sunda strait. Indonesia qualitative seminar and workshop 2019.

Suhirwan, P., \& Prakoso. (2020). Archipelago state strategic ocean tracker (1 st edition). CV. nas media library.

Prakoso, L.S., \& Sianturi, D. (2019). The Importance of cultivating national values for the frontier island coastal communities as an effort for citizens' participation in state defense. Marine Defense Strategy, 5(3), 117-132

Law number 3 of 2002 Concerning national defense.

Law Number 20 of 2003 Concerning the National Education System.

1945 Constitution.

Yulida, M. (2017). Accessed 17 September 2018. 